Marek Cetwiński

\title{
Watki prawne w polskich legendach herbowych
}

\section{Rechtsfäden in polnischen Wappenlegenden}

1. Legenda - rzeczywistość. 2. Motywy bratobójstwa. 3. Ideały szlacheckie $w$ legendzie herbowej. 4. Precyzja legendarnego obrazu szlacheckiej rzeczywistości

1. Legende - Wirklichkeit. 2. Brudermordmotive. 3. Adlige Ideale in der Wappenlegende. 4. Präzision des legenderen Bildes der adligen Wirklichkeit.

1. Swiat legend herbowych to świat literackiej fikcji pragnącej naśladować świat rzeczywisty. Nie brak $\mathrm{w}$ nim więc i takich opowieści, które początek herbu wiążą z czynem wyczerpującym znamiona przestępstwa. Bohater heraldyczny popada wówczas w konflikt $\mathrm{z}$ obowiązującym w świecie legend prawem. Rodzi się zatem pytanie, jakim to prawem rządzi się wyobraźnia heraldyków: czy w świecie legend akceptowane są w pelni te same co w świecie realnym systemy norm?

Opowiada Bartosz Paprocki, jak to pewien rycerz zabił rodzonego brata, przeto, iż córke jego, dziedziczke, wydal za maż, z wolq księcia pruskiego za jednego stuge tego ksiażzecia ${ }^{1}$.

1 B. P a p r ock i, Gniazdo cnoty, Kraków 1578, s. 1091; stosowny fragment daje też M. K a z a ń czu k, Staropolskie legendy herbowe, Wroclaw 1990, s. 164 . 
Przyczynę tego bratobójstwa w sposób w pełni zrozumiały wykłada nasz autor w Herbach rycerstwa polskiego ${ }^{2}$. Opowiada on, jak w Prusach zmarł pewien rycerz herbu Wręby alias Korczak, pozostawiając dwóch synów. Jeden $\mathrm{z}$ nich nie miat potomka męskiej ptci, tylko córke; tej gdy się napierano $u$ niego, nie tak wiele dla onych bogactw, które jej po ojcu wlaśnie należaly, jako dla pięknej urody, która gdy ojciec odmawiat, brat jego, a stryj onej panny, dostawszy jej dal za mąż. Ojciec przyjechawszy, majac sprawe o wszystkim dostatecznq, nabieżawszy brata zabil mówiqc: „Że tobie nie przystalo się niq opiekować pókim ja żyw". Wtem matka onej panny $z$ żatościa $i$ dla frasunku o taki despekt prędko umarta. On sie ożenil, a potem pojednawszy sie $z$ synowcy o glowe, to mial za wieczny znak, że mu ten herb obrócono, a czarnych pól używać kazano. A i we wcześniejszym Gnieździe cnoty pisze Paprocki, iż odmiana herbu Nabrama była warunkiem ugody $\mathrm{z}$ synowcami.

Mamy więc w tej legendzie i zabójstwo i pojednanie zabójcy, $\mathrm{z}$ rodziną ofiary. Zemsta, okup i pojednanie to rzeczy dobrze znane prawu polskiemu ${ }^{3}$. Winny zabójstwa płacił główszczyznę i dopełniał pokory, jeśli ofiara była mu stanem równa ${ }^{4}$. Pokora to także nazwa herbu rycerskiego przedstawiającego podkowę $\mathrm{z}$ przełożonym przez nią kluczem. Według legendy, herb ten nadano pewnemu rycerzowi na pamiątkę pielgrzymki do Rzymu,

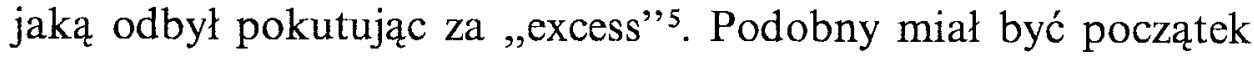
herbu Pobóg, tyle, że tym razem bohater pielgrzymuje do Rzymu, aby uzyskać papieskie rozgrzeszenie za czyn swego

${ }^{2}$ B. P a procki, Herby rycerstwa polskiego, wyd. K. J. Turowski, Kraków 1858, s. 693.

3 J. B a rdach, Historia państwa i prawa Polski, t. I, do polowy XV wieku, Warszawa 1964, s. 526 i n., tam też starsza literatura.

${ }^{4}$ H. Za r em sk a, Banici w średniowiecznej Europie, Warszawa 1993, s. 88 i n.

${ }^{5}$ B. Paprocki, Gniazdo..., s. 1132; K. Niesiecki, Herbarz polski, t. VII, wyd. J. N. Bobrowicz, Lipsk 1841, s. 356. 
przodka, winnego bratobójstwa ${ }^{6}$. Obie te legendy nawiązują w widoczny sposób do przyjętego pod wpływem prawa niemieckiego zwyczaju pielgrzymki zabójcy do miejsc świętych, jako warunku poniechania zemsty przez rodzinę ofiary? . Wystarczy tych przykładów, by uznać, że prawo, jakim się rządził świat legend herbowych, to świat prawa panującego $w$ Polsce XIV-XV w.

2. Motyw bratobójstwa jest w legendach herbowych dość częsty. Krewnobójstwo interesuje heraldyków w stopniu nie mniejszym, niż twórców Statutów Kazimierzowskich ${ }^{8}$. Zakończona tragicznie waśń rodzonych braci stanowi treść innych jeszcze legend o narodzinach herbów: Orla, Mądrostki, Niezgoda, Korczbok i Pomian 9 . Z kolei o krzywdzie wyrządzonej rodzeństwu przy podziale ojcowizny wspominają legendy herbu Krzywda, Stary Koń i Rawicz ${ }^{10}$. We wszystkich tych przypadkach rzecz

${ }^{6}$ B. Pa procki, Gniazdo..., s. 201; M. K a z án czuk, Staropolskie..., s. 175.

${ }^{7}$ H. Zaremska, Banici.., s. 83 i n.

${ }^{8}$ Szerzej o tym: M. Ka z á́czuk, Staropolskie..., s. 105 i n., gdzie też ze smakiem podany aforyzm J. Le Goffa, Kultura średniowiecznej Europy, thum. H. Szumawska-Grossowa, Warszawa 1970, s. 284: Ród feudalny w naturalny sposób wydawal Kainów. O mitologicznych uwikłaniach motywu bratobójstwa zob. M. Cetwiński, M. Derwich, Herby, legendy, dawne mity, Wrocław 1987, według indeksu legendy herbowe bratobójstwo, zajazd na dwór brata.

${ }^{9} \mathrm{~K}$. Niesiecki..., Herbarz, t. VII, s. 127-128 (Orla); ibidem, t. VI, s. 319-320 (Niezgoda); ibidem, t. VI, s. 567-568 (Mądrostki); ibidem, t. V, s. 257-258 (Korczbok); B. P a procki, Gniazdo..., s. 1012 (Pomian).

${ }^{10} \mathrm{~K}$. Niesiecki, Herbarz..., t. V, s. 419 (Krzywda); M. Cetwiński, Wokól legendy heraldycznej Starych Koni, „Prace Naukowe WSP w Częstochowie. Zeszyty Historyczne" 1993, t. I, s. 41-50, gdzie dalsza literatura i podstawa źródłowa; o Rawiczu zob. M. Ka z án c zuk, Staropolskie..., s. 62 i n., a zwlaszcza R. K i e r s nowsk i, Niedźwiedź i panna. U źródel jednej $z$ legend heraldycznych, [w:] Biedni $i$ bogaci. Studia $z$ dziejów spoleczeństwa i kultury ofiarowane Bronislawowi Geremkowi w sześćdziesiąta rocznice urodzin, Warszawa 1992, s. 282-293. 
kończy siẹ zerwaniem dotychczasowych więzów rodzinnych, co symbolicznie wyrażane jest przyjęciem przez jedną z gałęzi rodu nowego herbu. Jeśli herb zmieniają zabójcy, to - zdaniem heraldyków - jest to kara; nowy herb ma wiecznie przypominać o hańbie zabójcy ${ }^{11}$. Pozbawieni wiẹc zostają - zgodnie ze Statutami Kazimierzowskimi - zarówno ,ojcowizny", czyli w tym wypadku starego, odziedziczonego po przodkach herbu, jak też - znowu w z zgodzie z powołanymi prawami - „dobrej sławy i czci na wieczne czasy"12.

Niekiedy jednak to pokrzywdzeni domagają się ,,rozdzielenia herbów". Jest tak w przypadku oddzielenia się Starych Koni od Toporów ${ }^{13}$. Ale tak w jednej, jak i w drugiej sytuacji powstaje nowa wspólnota herbowa. Wspólnota, którą z braku lepszego terminu historycy określają mianem ,rodu”, składając tym samym nieświadomy hołd cieniom Lewisa Henry'ego Morgana i Fryderyka Engelsa ${ }^{14}$. Staropolskie herbarze kreślą obraz owych wspólnot, jako związku rodzin wywodzących się od wspólnego przodka. Takie zaś Klejnoty, najstarszy znany polski herbarz, piszą nawet wprost o wspólnych cechach fizycznych i psychicznych współklejnotników ${ }^{15}$. Niezwykle rzadko też mówią o domniemanym przodku, jako oczywistym plebejuszu. I w tych przypadkach okazuje się zazwyczaj, iż to nie tyle plebejusz, ile bohater obdarzony nadprzyrodzoną mocą - postać raczej nie

${ }^{11}$ M. K a z a ńczuk, Staropolskie..., s. 105, i stosowne teksty samych legend.

12 Warto w tym miejscu wspomnieć o tłumaczeniu Statutów Kazimierza Wielkiego przygotowanym do druku przez T. K. Kubickiego, Wydzial Prawa i Administracji UŁ (1993).

13 Szerzej: M. Cetwiński, Wokól legendy..., s. 41 i n.

${ }^{14}$ Szerzej: M. Cetwiński, ,Rody" piastowskiej ,marchii zachodniej” oraz W. S emkowicz, O średniowiecznym rycerstwie ślaskim, Genealogia, t. III, 1993, s. 83-93; t e nże, ,Przewodnik wyborny". Poczqtki kryterium imionowego $w$ badaniach nad spoleczeństwem Polski piastowskiej, Genealogia, t. V, 1995, s. 87-106.

15 Szerzej: M. C e tw i ńs k i, Wokól „Klejnotów”, [w:] Genealogia - studia nad wspólnotami krewniaczymi i terytorialnymi w Polsce średniowiecznej na tle porównawczym, Toruń 1987, s. 127-148. 
z tego świata ${ }^{16}$. Zwykle zaś przodek jest już formalnie członkiem stanu rycerskiego. Złościło to okrutnie Stanisława hrabiego Mieroszewskiego. W swym dziełku $O$ heraldyce polskiej stwierdzał bowiem, że opowieści te są niekonsekwentne, gdyż rycerze i komesi nobilitacji nie potrzebujq ${ }^{17}$. Pominął jednak uczony hrabia, że legendy herbowe prawią o początku herbu tylko, nie o otrzymaniu szlachectwa. Szlachectwo i herb to - zdaniem naszych herbarzy - dwie różne sprawy: herb można było odmieniać, szlachcicem trzeba się było urodzić. Królowie w naszych legendach herbowych zwykle nadają - nieraz nawet na wyraźne żądanie zainteresowanego - tylko herby, zaś rzeczywistych nobilitacji udzielają nader powściągliwie. I ten rys wydaje się wzięty $\mathrm{z}$ rzeczywistości. Właśnie od Statutów Kazimierza Wielkiego jedynym rozstrzygajacym czynnikiem decydującym o przynależności do stanu szlacheckiego jest urodzenie $^{18}$. Wątpliwości co do szlachectwa władne stają się rozstrzygać sądy ziemskie, które wymagają i którym wystarczy przysięga odpowiedniej liczby i odpowiedniej kategorii świadków, iż taki to a taki jest nasz brat, naszego klejnota, naszego szczyta i nasza krew ${ }^{19}$. "Brat" jest tu pojęciem metaforycznym tylko. Wprowadzenie instytucji nagany szlachectwa rodzi potrzebę rodów heraldycznych, tych swoistych towarzystw asekuracyjnych, zespołu świadków gotowych potwierdzić przynależność jednostki do stanu uprzywilejowanego ${ }^{20}$. Nie dziwi

${ }^{16}$ M. C e twińs ki, Bohater polskiej legendy heraldycznej, ,Acta Universitatis Wratislaviensis" 1993, Historia CVI, s. 41-52.

${ }^{17}$ S. Mieroszowski, O heraldyce polskiej, Lódź, b. r. (przedruk, Kraków 1887), s. 53.

18 J. S. M a tuszewski, Nagana szlachectwa w Polsce w XV $i$ XVI wieku, „Zeszyty Naukowe Uniwersytetu Lódzkiego” 1971, ser. I, Nauki humanistyczno-spoleczne, z. 77 , s. 126.

19 Ibidem, s. 126 i n. o poważnych następstwach tej praktyki dla wzrostu liczebności stanu szlacheckiego.

${ }^{20}$ Ibidem, s. 144 na około 2500 zapisek, tylko w czterech przypadkach naganiony nie udowodnil swego szlachectwa, co stanowi ,zaledwie $2 \%$ ogólnej liczby". 
zatem, że „rody heraldyczne" poświadczone są źródłowo w działaniu niemal wyłącznie podczas sądowego postępowania o oczyszczenie naganionego szlachectwa ${ }^{21}$. Skoro szlachcicem trzeba się urodzić, to nie dziwi, iż starannie tworzy się tradycję o pochodzeniu współklejnotników od wspólnego przodka. Najlepiej - już też szlachcica. Nie dziwi też fakt, że nazwy owych ,rodów” pojawiają się dopiero w epoce Statutów Kazimierzowskich. Pierwszym zaś kronikarzem używającym ich przy prezentacji swych bohaterów jest wspólpracownik Kazimierza Wielkiego $\mathrm{z}$ ostatnich lat panowania króla - Janko z Czarnkowa ${ }^{22}$. Wprowadzona przez Statuty zasada rodzi nie tylko odpowiednie procedury sądowe, tworzy de facto same „rody”, a w dalszej konsekwencji sprawia, iz pojawiają się legendy herbowe $\mathrm{i}$ herbarze. Te ostatnie są nie tylko pomnikiem szlacheckiej chwały. Są też - siłą rzeczy - poradnikiem dla chcących szlachectwo uzyskać, ułatwiając - tak wówczas, jak i dziś - wybór herbu, tradycji i krewnych.

3. Legendy herbowe są - według Józefa Ignacego Kraszewskiego - poezją, jaka przodkowie nasi poklonili się idealom swoim ${ }^{23}$. Również ideałom prawnym. Najważniejszym z nich stawał się ideał absolutnej władzy stanu szlacheckiego. Są więc i takie legendy, które zawierają pochwałę królobójstwa. Znamy je dwie. Pierwsza mówi o początkach herbu $O k s z a^{24}$, druga - o na-

21 Zauważmy jednak, że taką samą procedurę oczyszczającą stosowano, gdy szlachcicowi zarzucano kryminalny występek np. kradzież.

${ }^{22}$ Zob. J. B i e n ia k, Heraldyka polska przed Dlugoszem, Uwagi problemowe, [w:] Studia i ideologia $X V$ wieku, red. P. Sku bis zewski, Warszawa 1978 , s. 165 i n.

23 J. I. K r aszewski, Gawedy o literaturze i sztuce, Lwów 1857, s. 336. M. Kazańczuk, Staropolskie..., s. 7 slusznie uznaje te słowa za kwintesencje uwag Kraszewskiego.

${ }^{24}$ B. P a procki, Gniazdo.., s. 701-702. 
rodzinach herbu Korczak ${ }^{25}$. Herb Oksza miał nadać jeszcze Bolesław Krzywousty - wiara w odwieczność herbów również jest następstwem przyjętej przez Statuty Kazimierzowskie zasady szlachectwa $\mathrm{z}$ urodzenia - Janowi Werszowcowi po zabiciu przez tego bohatera złego władcy, czeskiego księcia. Jan otrzymał nowy herb, gdyż nie chciał już więcej używać poprzedniego - Wierszy. Królobójstwo jako obowiązek szlachetnego rycerza przedstawia też legenda Korczaków. Mówi ona o tym, jak to Węgrzy przez tragiczny zbieg wydarzeń musieli swym królem obrać psa. Biedne zwierzę z dość oczywistych powodów nie potrafiło utrzymać monarszej powagi i przodek rodu Korczaków zabił psa wybawiając Węgrów z niezręcznej sytuacji. Podkreślić tu należy delikatność Paprockiego. Oba te królobójstwa nie dotyczą bowiem monarchów Polski. Są jednak wystarczająco wyraźną aluzją do tak hołubionego przez naszą szlachtę prawa oporu.

4. Szlachta jest więc - tak w legendach herbowych, jak w rzeczywistości - prawdziwym władcą kraju. Nieograniczona jest też władza szlacheckiego ojca rodziny. Wszak Nabram zabił swego brata dlatego, iż ten uzurpował sobie prawo decydowania - losie bratanicy, jeszcze za życia jej ojca. Legenda herbu Paprzyca głosi zaś, że mąż jest sędzią czynów swej żony. Bowiem według tej legendy pewna pani, bojąc się posądzenia - małżeńską niewierność, kazała utopić ośmiu z dziewięciu synów, jakich właśnie na raz porodziła ${ }^{26}$. Do dzieciobójstwa szczęśliwie nie doszło. Dzieci z rozkazu pana wychował pewien młynarz. Kiedy synowie podrośli, pan sprosił sąsiadów i zapytał ich, na jaki los zasługuje wyrodna matka. Jednomyślnie orzeczono, że zasługuje na śmierć. Jednak - jak przystało na

${ }^{25}$ M. Kazańczuk, Staropolskie..., s. 47 i n., gdzie teź dalsza literatura.

${ }^{26} \mathrm{O}$ tej legendzie szerzej: M. Cetwiń ski, Mlynarz, mlyn i żarna $w$ genealogii $i$ heraldyce polskiej, „Acta Universitatis Wratislaviensis” 1991, Historia LXXXII, s. 53-65, tam też dalsza literatura. 
przypowieść umoralniającą - mąż żonie wybaczył. Istotne jest wszak właśnie to podkreślenie prawa męża do decydowania nawet o życiu żony. I taki był zatem ideał szlachecki.

Nieograniczona jest także władza pana nad shugą. Prawo do dysponowania jego życiem $\mathrm{i}$ śmiercią jest ideą obecną $\mathrm{w}$ legendzie herbu Prosna. Jej bohater, broniąc zamku w Przemęcie, w stanie jakby wyższej konieczności zabija swego sługę, aby włożyć w ubranie martwego sługi listy mające zmylić wrogów ${ }^{27}$. Nie nam jednak negatywnie oceniać moralną stronę tego - w pojęciu herbarzy - bohaterskiego czynu. Wyraźnie przestrzegaja przed tym inne legendy. Jedna $\mathrm{z}$ nich, opowiadając o początkach herbu Pomian, łączy tę przestroge $\mathrm{z}$ motywem bratobójstwa ${ }^{28}$. Paprocki pisze:

\section{Lastek Chebda de Grabie brata}

Zabil we wsi Lubania, czlowieka zacnego,

Jaranda gnieźnieńskiego dziekana, dlatego,

Iże go upomnial $z$ wielu zbytków jego.

Dalej jest mowa - jak zwykle w herbarzach - o odmianie herbu spowodowanej księżo- i bratobójstwem. Ale potępienie ze strony Paprockiego jest dość umiarkowane w tonie. Heraldyk zdaje się rozumieć motywy kierujące zabójcą. W każdym razie nie przypisuje tu, jak w legendzie Mądrostków, winy zdradzieckim knowaniom Czarta ${ }^{29}$. Legenda herbu Pogwizd opowiada natomiast, jaki los spotkał chłopów wyśmiewających się $\mathrm{z}$ pijanego szlachcica ${ }^{30}$. W Mazowszu wiele domów rycerskich tego herbu używa [...], mieniqc to, że przodek herbu tego wiele byt

${ }^{27}$ B. Paprocki, Gniazdo..., s. 1073-1074.

${ }^{28}$ Klejnoty Dlugoszowe, krytycznie opracowal $i$ na nowo wydal Dr Marian Friedberg, Kraków 1931 (,Rocznik Polskiego Towarzystwa Heraldycznego" 1930, t. X), s. 82-83; B. Pa procki, Gniazdo..., s. 1012.

${ }^{29}$ B. P a p rocki, Gniazdo.., s. 1103: „Czart, który na spokojne ludzi zwykl nachodzić...".

${ }^{30}$ B. Paprocki, Herby..., s. 560. 
chtopstwa, jadac $w$ nocy $z$ miasta pijany, gdy za nim świstali, kazawszy woźnicy stanać, posiekt ${ }^{31}$. Interesująca jest tu paralela między heraldycznym bohaterem a Noem przeklinającym rodzonego syna - Chama ${ }^{32}$. Nie przypadkiem też Noe jest jednym $\mathrm{z}$ bohaterów Herbów rycerstwa polskiego ${ }^{33}$, upatrujących w nim twórcę religii i kultury. Szlachcic polski jest takim samym twórcą świata cywilizowanego, jak praojciec Noe, rozpoczynający odbudowę świata po katastrofie potopu. Szlachcic, tak jak Noe, nie może być przedmiotem jakiejkolwiek krytyki, a zwłaszcza wtedy, gdy wychodzi ona od „chamów”.

Zdaniem legend herbowych, krytyka postępowania szlachty ze strony chłopów, a nawet ze strony duchowieństwa, jest zdecydowanie niewskazana. Podobnie jak niedopuszczalne są wszelkie próby uszczuplenia praw szlacheckich przez państwo, zwłaszcza w tak delikatnej sferze interesów materialnych, o czym mówią legendy Rawiczów i Osoryi. Obie wspominają o trudnościach z wywiezieniem z kraju ,skarbów" odziedziczonych przez małżonki bohaterów. W legendzie o początkach herbu Rawicz prawi się o pewnym „królu angielskim”, który majątek swój podzielił, zresztą zgodnie z zaleceniami prawa polskiego, między syna i córkę ${ }^{34}$. Temu pierwszemu przypadła ziemia, dziewczyna zaś otrzymała „,klejnoty”. Panowie angielscy obawiając się, że skarby $\mathrm{z}$ chwilą zamążpójścia królewny opuszczą Anglię, doradzili młodemu władcy, by uśmiercił siostrę. Nieszczęsną wtrącono - zgodnie $z$ tą radą - do jaskini zamieszkałej przez przyuczonego do rozszarpywania skazańców (najpewniej po prostu głodzonego?) niedźwiedzia. Jednak dobry Bóg, który niegdyś ocalił Daniela $z$ jamy pełnej lwów, i tym razem interweniował. On - jak to wynika $\mathrm{z}$ legendy - w sposób widoczny

31 Ibidem s. 560.

32 O Chamie i chamie zob. znakomite studium J. Matuszewskiego, Cham, Łódź 1991.

${ }^{33}$ B. Pa procki, Herby..., s. 50. Por. M. Cetwiński, Bohater.., s. 47-48.

${ }^{34}$ B. Paprocki, Gniazdo..., s. 50-51. 
opowiedział się za wolnym transferem ruchomości, stanowiących posag szlacheckiej żony.

W kolejnej, zajmującej się obrotem dóbr ruchomych, legendzie: opowieści o początku herbu Osorya - obywa się bez bezpośredniej ingerencji Opatrzności. Tym razem - jak opowiada Paprocki - polski rycerz bogatą dziedziczkę poślubił w Czechach. Po śmierci teścia zapragnął $\mathrm{z}$ żoną $\mathrm{i}$ jej skarbami powrócić do Polski. Ale król czeski i tamtejsi panowie zabronili bohaterowi wywozu skarbów. Ów jednak przemyślnie wydrążył koła swych wozów, a także inne przedmioty i wlał w nie złoto, wywożąc je, czy raczej przemycając do ojczyzny. Czyn ten spotkał się $\mathrm{z}$ uznaniem rodaków i polski monarcha nadał na wieczną rzeczy pamiątkę rycerzowi stosowne godło ${ }^{35}$.

Wydaje się, że legendy herbowe zawierają pociągającą dla szlachty ideologię: nie tyle rycerz państwu, co państwo winno służyć rycerzowi. A jeśli król interweniuje w stosunki między szlachtą, to - zdaniem herbarzy - baczyć powinien, aby się to z widoczną szkodą jednej ze zwaśnionych stron nie odbyło. I tak kreśli Długosz scenę podobną tej, w jakiej Lew Tołstoj kazał się spotkać księciu Andrzejowi z tak przezeń podziwianym Napoleonem. Pisze więc kanonik krakowski, jak to nazajutrz po bitwie pod Płowcami Władysław Łokietek, objeżdżając pobojowisko, natknął się na straszliwie poranionego rycerza ${ }^{36}$. Monarcha przyjrzał się bacznie rannemu, wyraził współczucie i zwrócił się do otaczających rycerzy ze słowami: Jak ciężko cierpi ten nasz rycerz, którego ogladamy ${ }^{37}$. Skłuty wieloma włóczniami, przytrzymując rękami wypływające wnętrzności, Florian Szary westchnąwszy odpowiedział: Dotkliwsze to cierpienie, jeżeli ktoś musi znosić mieszkającego z nim w tej samej

35 Ibidem, s. 85; M. Cetwińs ki, Czesi i Morawianie w polskich legendach heraldycznych, „Biuletyn Instytutu Filozoficzno-Historycznego WSP w Częstochowie" 1995, $\mathrm{nr} 4$, s. 10-11.

${ }^{36}$ Omawia ją M. K a zańczuk, Staropolskie..., s. 23.

37 Jana Dlugosza Roczniki czyli kroniki slawnego Królestwa Polskiego, ksiega dziewiąta, tłum. J. Mrukówna, Warszawa 1975, s. 212. 
wsi uciażliwego sq̨siada. Łokietek, nie znajdując innego sposobu rozwiązania tego sąsiedzkiego konfliktu, aby uwolnić Floriana od przykrego sąsiada obdarza go nowymi dobrami.

Do niezbędnego minimum sprowadza się też legendarna interwencja króla w opisie początków herbu Dębno ${ }^{38}$. Kiedyś pewien tatarski murza wpierw porwał, a później ożenił się z dziedziczką na Dębnie. Ochrzcił i żył przykładnie, aż

...rycerz, co Abdank nosil, ku czci mu przymówil

Aniś godzien z dobrymi mieć spolku żadnego

Gdyżeś ty jest z narodu psiego, pogańskiego ${ }^{39}$.

Neofita poprosił króla o pozwolenie wyzwania przeciwnika na sąd boży i:

Zbil mężnie Abdańczyka, a w tym król zawolal Abyś mie jego gardlem dziś prosze darowal.

Rycerz - co oczywista - nie odmówił prośbie monarszej i Abdańczyk zachował życie, zaś Tatarzyn pozyskał nowy herb. Jakże tu wymowne lagodne potraktowanie szlacheckiego przeciwnika. Tak bardzo odmiennie potraktowano wszak i dziekana Jaranda i nieszczęsnych, a pyskatych chłopów w wyżej cytowanych opowieściach Pomianów i Poświstów.

Szlachcic winien darzyć szlachcica szczególnymi względami. Gdy tylko się da, to szlacheckie życie nawzajem oszczędzać. Pyszny Abdańczyk za królewskim wstawiennictwem zachowuje gardło nienaruszone. Cudownie powracają też do życia pokonani w sądzie bożym przeciwnicy rycerza Halki ${ }^{40}$. Zgodnie $\mathrm{z}$ obo-

${ }^{38}$ B. P a procki, Gniazdo..., s. 1041-1042. Analizuje legendę M. De rw ich, Legenda herbu Debno. Wersja tatarska, „Herald” 1990, nr 1, s. 28-33.

39 B. P a procki, Gniazdo..., s. 1042.

40 Ibidem, s. 209-210. Omawia ją: M. Cetwiński, Rycerz Halka i król Bolestaw Śmialy, [w:] 400-lecie Unii Brzeskiej. Tlo polityczne, skutki spoleczne $i$ kulturalne, red. A. J. Zakrzewski, J. Fałowski, Częstochowa 1996, s. 211-218. 
wiązującym w szlacheckim państwie prawem, także i w świecie legend herbowych życie szlachcica jest zdecydowanie cenniejsze niż życie plebeja.

Legendy herbowe dokumentują - rzecz jasna w niepełny sposób - stan świadomości prawnej stanu szlacheckiego. To całkowicie niezamierzony przez prawodawcę skutek Kazimierzowskich Statutów. Legendy mają być dodatkowym uzasadnieniem przywilejów posiadanych i pożądanych przez szlachecki ogól. Pozostając tworem literackiej fikcji, nie różnią się zbytnio od dzieł historiograficznych. Pełnią tę samą, co one funkcję społeczną. I jak one mieszają starannie relacje o wydarzeniach rzeczywistych z opowieściami mitycznymi. Pisze wszak Stefan Czarnowski: To, co stanowi istotna treść historii, jest legendq - niczym więcej, legenda uprawniajaca do takich czy innych przywilejów. - A forma historii wzorowana jest na micie. - Wynik uszeregowania $w$ czasie watków obrzędowych (ofiarniczych i potlatchowych) oto historia ${ }^{41}$. I dodaje: Krzyżowanie się każdorazowych zdarzeń doświadczenia teraźniejszego z przekazanq, normujaca ich postać forma wątkowa ${ }^{42}$. Takim też wnioskiem zakończyć wypada te wstępne rozważania na temat wątków prawnych w polskich legendach herbowych. Legendach, które najpewniej nie pojawilyby się w znanej nam formie, gdyby nie - powtórzmy - wprowadzona przez Kazimierzowskie Statuty „rodowa” forma organizacji stanu szlacheckiego. Bo - warto to mocno podkreślić - nie opisał $w$ nich prawodawca dotychczasowej w tym względzie praktyki; on ją właściwie dopiero zainspirował.

${ }^{41} \mathrm{~S}$. Czarnowski, Powstanie $i$ spoleczne funkcje historii, [w:] tenże, Dziela, t. V, Warszawa 1956, s. 102.

42 Loc. cit. 